\title{
The Role of Specialist Legal Institutions in Bargaining Under the Employment Contracts Act 1991: Saboteurs or Saviours?
}

\section{Lorraine Skiffington *}

This article examines the role of the "new" legal institutions in bargaining under the Employment Contracts Act 1991 through an analysis of case law and legal research. It provides an overview of bargaining provisions specifically addressing: choice of representatives, authorisation, recognition, rights of access, negotiation and ratification and critically analyses how the legal institutions have interpreted bargaining provisions under the Act. It argues that the free market philosophy underpinning the new regime is fundamentally flawed and that "free bargaining" has failed to deliver a workable system. Contrary to the peripheral role envisaged by the Act for the "new" legal institutions they had little option but to intervene and assume a traditional role of balancing the competing interests of employer and employees. In the absence of a statutory mandate for intervention, they find themselves in an increasingly precarious position pointing to an urgent need for reform of bargaining provisions and clarification of their role.

"Certainly courts are not, and cannot be immune from criticism. All human institutions are imperfect - courts as well as tribunals" (Gerhart,1987: 131).

\section{Introduction}

The Employment Contracts Act 1991 (The Act) radically reformed bargaining in New Zealand replacing the traditional system of collective bargaining developed over a century with one that emphasised "free" bargaining. While a measure of consensus developed on the new bargaining regime, the future role and structure of the specialist legal institutions continued to be a source of contentious debate.

Proponents of a specialist jurisdiction argued that the employment relationship was not simply another form of commercial contract, maintaining the Act was fundamentally flawed because it failed to acknowledge the inherent disparity of bargaining power between employer and employee. To redress the power imbalance, they called for the retention of a specialist jurisdiction claiming it was necessary to ensure the effective management of inevitable conflict.

* Employment Lawyer, Hamilton. The writer would like to thank Glyndwr Jones, Senior Lecturer, School of Management Studies, University of Waikato for his assistance with the preparation of this paper. 
Opponents of a specialist jurisdiction on the other hand argued that the employment contract was like any other contract, based on market exchange, and should be dealt with by courts of general jurisdiction. They contended that judicial intervention was philosophically inconsistent with the free market principles underpinning the Act. Under a deregulated system of free bargaining they claimed that the market would replace the courts as the sole arbiter of justice and, "lead to New Zealand joining the powerhouse economies of the world and bring true democracy to workplaces" (National Party, 1991).

The Act emerged as an inevitable compromise. The free bargaining framework advocated by the Business Roundtable and Treasury was adopted but their preferred institutional structures were rejected. A specialist employment jurisdiction survived albeit in a different guise.

Under the revamped specialist jurisdiction, the "new" legal institutions emerged with a radically redefined role. The emphasis on enterprise bargaining and mutual resolution of disputes between parties meant that the legal institutions no longer played a pivotal role in the bargaining process, ensuring equitable employment relations and providing protection for the parties. Instead the Act relegated them to a residual role of resolving disputes and differences arising from the breakdown of employment relations.

Early decisions under the Act signalled that the "new" legal institutions intended to take a cautious approach. In Adams v Alliance Textiles (NZ) Limited [1992] 1 ERNZ 982 the Employment Court made its intention clear not to intervene in the bargaining process stating, "the Act is quite specific as to the conduct which is prohibited and the Court is not justified in putting a gloss on the Act by importing a requirement nowhere expressed in it" $(989,1022$ 23) However, faced with increasingly problematic bargaining provisions that were incomplete, inconsistent or invisible, and incidents of bargaining practices that were the antithesis of playing fair "leading to unrest and disharmony and erosion of mutual trust and confidence thus producing an inefficient labour market and defeating the objects of the Employment Contracts Act 1991" (Service Workers Union of Aotearoa Inc. v Southern Pacific Hotel Corporation [1993] 2 ERNZ 513) the legal institutions had little option but to intervene.

Five years on the legal institutions have been forced to adopt an increasingly interventionist role by: establishing duties to ensure recognition of bargaining agents, defining negotiation and reintroducing the requirement for parties to bargaining in good faith. The alleged move towards "judicial activism" has led to intense criticism from employer and business groups who call for the abolition of the specialist jurisdiction and a return to common law and commonsense. Critics claim that the Act's intention to radically reshape the labour market is being sabotaged by these institutions who persist, against Parliament's intention, to interpret the Act as if the changes it made to the law were minimal (Howard, 1995: 1). Supporters of intervention, however, praise judicial activism asserting that the specialist legal institutions were the saviours of the system.

Amidst this continuing debate it is timely to examine the role of the "new" legal institutions and to assess their impact on bargaining under the Act through an analysis of the emerging case law. 


\section{The new bargaining regime}

Parts I and II of the Act are dedicated to bargaining. While the Act gives priority to establishing a bargaining framework, the provisions are prescriptive and permissive with an absence of detail and statutory direction.

The object of Part 1 of the Act is to establish freedom of association. In the context of labour law freedom of association is regarded as a fundamental human right usually joined with the right to organise and bargain collectively. These rights are set down in major international instruments, specifically ILO Convention 87 which concerns Freedom of Association and Protection of the Right to Organise and ILO Convention 98 concerning the Application of the Principles of the Right to Organise and Bargain Collectively. While New Zealand has failed to ratify these conventions they are still binding obligations on New Zealand, by virtue of its ILO membership.

Despite ILO obligations the Act adopts a broad interpretation of freedom of association and promotes employees' freedom to choose whether or not to enter into collective or individual bargaining arrangements. It emphasises an employee's individual right to enter into an employment contract which contrasts sharply with previous legislation whose central purpose was to facilitate collective bargaining, acknowledging the inherent imbalance of bargaining power between employer and employee. Reference to collective bargaining is conspicuously absent from the Act.

Part II of the Act provides a framework for representation and bargaining arrangements. Again the Act's overriding objective is to establish the right to choose bargaining representatives. Once chosen, a representative is required to establish their authority to represent an employee or employer under s.12(1) which states:

Any person, group, or organisation who or which purports, in negotiations for an employment contract, to represent any employee or employer shall establish the authority of that person, group, or organisation to represent that employee or employer in those negotiations.

This section, however, fails to provide any guidelines on what constitutes authorisation. Similarly s.12(2) requires that once:

an employee or employer has authorised a person, group, or organisation to represent the employee or employer in negotiations for an employment contract, the employee or employer with whom the negotiations are being undertaken shall, subject to $\mathrm{s} .11$ of this Act, recognise the authority of that person, group or organisation to represent the employee or employer in those negotiations.

Again this section fails to define recognition. Further complications arise where employers are obligated to recognise an authorised bargaining representative but are under no statutory obligation to negotiate with them. Just what practical assistance this would be to the process of bargaining was unclear.

The issue of access for bargaining representatives presented the institutions with another set of problems. While an authorised bargaining representative has a statutory right of access for the purpose of obtaining authority to act as a representative, rights of access for the purpose 
of negotiation are restricted to negotiations with "an employee" and are required to be at, "a reasonable time." Legal institutions were left the task of developing a working definition of reasonableness to facilitate the bargaining process. This is however nothing new. Statutes are frequently drafted as bare legislative frameworks leaving the development of detail up to the judiciary. Over the last five years, the interpretation of sections that provide only minimal statutory guidelines and drafting anomalies has resulted in a growing volume of controversial case law. Key issues regarding bargaining will be discussed as follows.

\section{Choice of representation}

Section 10 of the Act which establishes the freedom to choose a bargaining representative effectively disenfranchised unions from their exclusive right to represent employees. Under the Act, anyone can act as a bargaining representative (with exceptions based on criminal convictions under s.11 of the Act) as long as their authorisation is demonstrated. An objection to a chosen bargaining agent was raised in Sidebotham and Powell v Capital Coast Health Ltd [1994] 2 ERNZ 431 ${ }^{1}$.

\section{Authorisation}

Section 12 requires that any person who represents either an employer or employee in negotiation of an employment contract must establish their authority to do so. Again the Act does not indicate how the parties are to do this, something that was left for the courts to determine.

The first case to deal with authorisation made it clear that generalised statements of authorisation contained in union rules may not be sufficient. In New Zealand Nurses v Argyle Hospital Ltd [1992] 2 ERNZ 314 a bulk authorisation combined with an application for membership of the union was held to be adequate. The Employment Court stressed that while it was acceptable in the context of this particular case, a prudent union should obtain specific written authorities from each of the employees it represented. The Employment Court confirmed in New Zealand Baking Trades Etc Union (Inc.) v Foodtown Supermarkets Limited [1992] 3 ERNZ 305:

that while nothing in the Act prohibited the use of general authorities, it must be plain that this was the intention of the grantor before it may be relied upon. General provisions in union rules will not be adequate enough to authorise the union to take specific litigation on behalf of its members $(305,313)$.

1 This case involved a conviction under s.231 of the Crimes Act 1961 for fraudulently destroying a document. The Court declared the objection invalid as it involved a maximum penalty of three years which fell short of Parliament's arbitrary cut off point of five years imprisonment. Chief Judge Goddard cautioned that while the section had strict limits its application should be treated with care. Not only did it involve double punishment but it also involved an indirect penalty against those being represented. 
This strict interpretation was reaffirmed in NZ Dairy Workers Union Inc. v Hautapu Whey Transport Ltd [1994] 2 ERNZ 549 where the Court held that an employee could be a paid-up member of a union, without authorising the union to act as their bargaining representative, upholding the right of individual employees to choose their own bargaining representatives. In this case the Employment Court made it clear that, "a bargaining representative entitled to expect the Court to confirm its right of recognition by an employer must be appointed freely and genuinely according to the spirit as well as the letter of the legislation" $(549,568)$. The right of employees to withdraw a bargaining representative's authority to represent was emphasised recently in Billing v Wellington City Council (unreported WEC 33/95) where despite the withdrawal of their negotiating authority the union pressed on with negotiations and reached a settlement which was later ratified. The Employment Court, however, was unequivocal that the plaintiff employees were not bound by the collective employment contract. Case law continues to assert that authorisation of a bargaining representative is an absolute right of the employee who has total discretion to exercise that right.

\section{Initial difficulties with rights of access}

The Act provides a two fold right of access for bargaining representatives. Section 13 establishes the initial right of access for the purpose of obtaining authority to act as a representative which is conditional on the agreement of the employer. Section 14 establishes a more substantive right of access by an authorised representative for the purpose of negotiating an employment contract. Access must, however, be at any reasonable time. Whether the legislature anticipated the practical difficulties of obtaining an employer's consent, or the problems associated with defining what is a reasonable time or, intended access to be exclusive to the negotiation of an individual employment contract is a matter for speculation. While the Act purports to provide a substantive right of access for representatives, in practice its tenuous nature soon became apparent as some employers seized the opportunity to use the loopholes to their advantage.

This was evident in Argyle Hospital where an employer, having persuaded a number of its employees to sign two year individual contracts, refused access to the union official and served a trespass notice on him. The Employment Tribunal had no difficulty in upholding the union's right to access to the workplace. It also noted that notwithstanding the fact that most nurses had signed two year individual employment contracts, they were free at any stage to seek negotiation of a collective contract and that a union official was entitled to access for that purpose.

In Hawtin v Skellerup Industrial Ltd [1992] 2 ERNZ 500 an employer sought a penalty against a union for organising a stop work meeting during working hours to discuss a proposed collective employment contract. The employer claimed that the wording of s. 14 did not authorise stop work meetings, being explicitly expressed in the singular. While the Tribunal agreed that s. 14 was inherently contradictory, it took a commonsense approach to establishing the right of access which could include meetings with a group. The Tribunal stressed that access had to occur at a reasonable time which logically meant a time when production was not affected. In practice this meant restricting access to lunch times or other breaks during the day. 
While s.14 establishes the right of access for bargaining representatives, employers have considerable control over the actual terms of the access. In Alliance Textiles the employer granted access at $6 \mathrm{am}$ in the morning and then only after trying to convince their employees to rescind the authority they had given to the representative. Similarly in Argyle Hospital the employer only allowed the union representative the opportunity to speak to an employee in the corridor amidst the general flurry of workplace activity.

Section 14 places further restrictions on representatives' freedom to bargain by only permitting access for the purpose of discussing an employment contract. This effectively barred union access to the workplace to discuss with their members a range of other significant issues such education and training, leading to the criticism that the Act is highly selective about the freedoms it affords.

Early case law emphasised that while the Act establishes a right of access for bargaining representatives, this right is limited, reinforcing the underlying presumption that the workplace is the private property of the employer. While legal institutions maintained a strict adherence to the Act, limiting bargaining representatives' rights to the letter of the law, this contrasted starkly with the discretion afforded to employers under the Act who are given every necessary mechanism to control employment contracting at the enterprise level. It is not difficult to conclude therefore that the difficult process of gaining authority, recognition, and then access was devised as a deterrent to collective bargaining, where in practice bargaining representatives were all but banned from the workplace.

\section{Rights of access revisited}

The parameters of rights of access were comprehensively reviewed in Service Workers Union of New Zealand Aotearoa Inc v Southern Pacific Hotel Corp (NZ) Ltd [1993] 2 ERNZ 531. In this case employees sought compliance orders to restrain an employer from imposing restrictions on a union's entry and access to its members. The employer maintained that the peculiar nature of the industry and the requirement of health and safety procedures precluded any access to the work premises. After an examination of the statutory limitations on the right of entry, the Employment Court found that under s.14(2) the employer had to show that procedures or requirements existed relating to health and safety and that they were reasonable, and limited or prohibited the entry of persons other than employees. The Employment Court found that s.14 did impose restrictions on the representatives roaming at large through an employer's premises by requiring them to report on arrival and adhere to relevant health and safety regulations. However it concluded that:

where there is a right of entry and the exercise of the right is met with conditions or restrictions which are not authorised, then the right is as good as denied. To delay entry, to surround it with conditions of the employer's invention, and to impeded it is to refuse entry in breach of the prohibition in s.14(5). $(531,532)$

Rights of access under s.14 were further clarified by the Court of Appeal in Foodstuffs (Auckland) Ltd v National Distribution Union Inc [1995] 2 NZLR 280, where an employer refused access to an authorised bargaining representative for the purpose of negotiating an employment contract and refused to pay employees during a stop work meeting. Adopting 
a broad approach, the Court of Appeal confirmed that the general rationale of s.14 is "to facilitate the free and informed exercise through discussion of the choice already made which in this case was for a collective representative rather than of individual bargaining" ( 280 , 284).

The case is significant because for the first time the Court of Appeal recognised that the right of access included collective elements. Contrary to previous case law, the Court of Appeal had no difficulty in establishing that access was not restricted to individual negotiations but covered collective arrangements. Importantly the case reaffirmed that employees have the right of freedom of association and representation and the Act should be interpreted by the courts to support these choices. Furthermore the Court of Appeal noted that s. 14 rights were statutory and could not be contracted away.

Payment of stopwork meetings was also addressed in Foodstuffs. The Court of Appeal noted that stopwork meetings to discuss contract negotiations were most likely to be held during working time and concluded that:

it could hardly have been intended that pay should be deducted for any time however short, during which an individual stops what he or she is doing, or that it should be reduced while the individual works more slowly, during the discussion $(280,284)$.

The judgment stressed that "the Court must lean away from any construction that creates a disincentive to the exercise of the right of choice and representation" $(280,284)$. The Court made it clear that such a disincentive would follow from a deduction in pay whatever the terms of the employment contract.

The Court of Appeal came to the conclusion that bargaining access was governed by the overriding principle of reasonableness, pointing out "it is a matter of striking a fair balance between the employer's interests and those of the employees and their representatives." It was unwilling, however, to define what constitutes reasonableness but instead, identified several factors to be considered when determining reasonableness. These included: the degree of disruption anticipated, length of meeting time, frequency of entry requests, timing of request and prior notice. This test of reasonableness applies to both employers and bargaining representatives. In Skellerup Industries Ltd v NZ Rubber Workers Union [1992] 1 ERNZ 477 it was held that an employer was not given reasonable notice of a meeting which halted production. Similarly in Foodstuffs the Court of Appeal held that it was not reasonable to have on-going rights of access for negotiation once a contract had been concluded. Employers cannot, however, lawfully prevent authorised representatives from entering the workplace to discuss collective negotiations with their employees even if they subsequently sign individual contracts but do not withdraw the representative's bargaining authority.

\section{Ratification}

A concern under the previous system of centralised collective bargaining was that parties were rarely consulted and therefore had little control over the outcomes of award negotiations. In an attempt to address this deficiency, the Act included a mandatory ratification clause, intended to ensure that both parties understood and agreed to the terms of the contract. 
Section 16 stipulates that a ratification procedure must be in place three months prior to the commencement of negotiations. The details of the procedure are left to the discretion of the bargaining representative and those to be represented. The Act is silent on the role of employers in ratification and fails to provide protection against the undermining of the ratification process. These procedures were left for the legal institutions to develop.

The early cases dealing with ratification followed a strict interpretation of s. 16 noting that the agreed ratification procedure is binding. In Grut v Downer Mining [1992] 1 ERNZ 982 the union claimed that the employer had breached the agreed ratification process by talking directly with employees. The Employment Court held that this was permissible although it emphasised that the ratification process was strictly a matter between the union and its members.

In Shannon v Pacer Kerridge Cinemas Limited [1992] 3 ERNZ 742 it was held that once a contract is ratified, it will be upheld even if the employees subsequently withdraw their authorisation in an effort to invalidate it. In this case, the union agreed to drastic cuts in the wages of employees and ratified the contract without fully informing them at a ratification meeting. By the time the employees learned of this and withdrew their authorisation, the union confirmed with the employer that the contract had been ratified.

Similar circumstances arose in Butters v Forestry Corporation of New Zealand Limited (unreported, AET 880/92) where an employer acted on a ratified contract that employees subsequently tried to overturn by resigning from the union. The employer claimed that employees were estopped from denying the authority of the union to act on their behalf, notwithstanding the lack of ratification procedure. The case was, however, withdrawn before the Court could resolve the issue because of the employer desire to preserve an amicable working relationship which took precedence over any potential benefit of succeeding in an action on a legal technicality.

Both Butters and Shannon illustrate that while the ratification procedure is mandatory, without detailed provision to ensure its enforcement the Act potentially increases the employer's ability to undermine collective contracting. Where the Act is silent, the Courts had little option but to reinforce the sanctity of a concluded contract and to give full weight to it.

Subsequent case law has, however, modified this approach where the legal institutions have taken the view that attempts to influence the ratification procedure may breach $\mathrm{s} .12$ and raises questions as to whether the employer is exerting undue influence and is therefore in breach of s.57. In NZ Engineering Union Inc and Ors $v$ Shell Todd [1994] 2 ERNZ 546, an employer attempted to withdraw from a settlement (prior to ratification) after discovering it had made an error by agreeing to a clause. The Employment Court held that pending ratification, "the employer cannot resile from its commitment, for it is inherent in s. 16 that what is put forward for ratification is the settlement reached and not something else." The Employment Court concluded that it was not open to the employer to deprive employees of the opportunity to ratify the settlement by simply changing its mind.

Attempts to alter settlements after ratification were also addressed in Armstrong $v$ AttorneyGeneral [1995] 1 ERNZ 43 where the Employment Court held that the practice of introducing 
new material into contracts after ratification was highly questionable and that tampering with ratified terms of settlement was most improper and probably constituted a breach of s.12 of the Fair Trading Act 1986.

In NZ Medical Laboratory Workers Union v Capital Coast Health Ltd [1994] 2 ERNZ 123, the Employment Court further clarified the role of ratification when addressing the emerging practice of undermining settlements at the ratification stage. It made it clear that while ratification is the procedure for concluding negotiations, it is implicit in s.16 that once a proposed settlement is reached it binds both parties subject to ratification, adding that the contract is made at the time of settlement.

Since the passing of the Act, legal institutions have progressed some way towards establishing a framework of ratification that balances the competing interests of employer, employees and bargaining representatives, while at the same time avoiding compromising the intention of the Act.

\section{The process of negotiation}

In contrast to previous legislation which imposed a highly regulated collective framework for contract negotiation, the Act fails to establish any substantive process for negotiation. As stated in Buchanan v Rodney District Council [1992] 2 ERNZ 578:

The Act generally contemplates that there will be negotiation. There are however no rules or other practical provisions indicating how, when, where and for how long. The only aspects clearly covered are with whom the negotiation process should be conducted. There is no longer a legitimate expectation of negotiation $(578,585)$.

When negotiation does take place, there is no statutory requirement that it be carried out fairly, an important consideration when employees, without the collective strength of their union, may be at a disadvantage in their bargaining position. As Keily and Caisley (Harbridge, 1993: 60) point out:

Despite the imbalance of bargaining power inherent in the permissive framework of negotiation established under the Act, it might have been hoped that the Courts would have evened up the situation by:

(i) imposing a requirement to negotiate in good faith

(ii) incorporating substantial duties into the obligation to recognise the bargaining agent

(iii) defining negotiation to include some element of compromise.

The initial case law indicated, however, that the Courts were reluctant to impose such an interpretation on the Act.

The issue of negotiating in good faith was debated at length by the Employment Court in Alliance Textiles, where an employer who recognised the union as a bargaining representative subsequently discouraged workers from enlisting its services and obstructed the union's attempts to negotiate. The central question for the Court was whether the employer's tactics 
amounted to harsh and oppressive behaviour, or involved undue influence or duress for the purposes of s. 57 of the Act.

Due to the uncharacteristically high criminal burden of proof required to establish harsh and oppressive behaviour under the Act, the Employment Court noted that the notoriously robust exchanges typical of the New Zealand industrial relations scene, though unfortunately confrontational, is still the style in which many employers and employees do business with each other. Reluctant to intervene, the Employment Court stated:

The Act is quite specific as to the conduct which is prohibited and the Court is not justified in putting a gloss on the Act by importing a requirement nowhere expressed in it, that the employer should remain neutral when its vital interests are affected and maintain in that situation a 'hands-off' stance $(982,1023)$.

Attempts to impose an obligation on employers to negotiate with bargaining representatives in good faith continued to fail, with the legal institutions taking a narrow interpretation that an employer was under no obligation to negotiate at all. Case law illustrates that if an employer did agree to negotiate, they were under no obligation to compromise. This was apparent in Skellerup where it was held that the Act enables an employer, without any prior negotiations, to present an otherwise lawful collective employment contract to its employees and insist that, unless they accept its terms within a prescribed time, they would be locked out. In this case, the Employment Court conceded that in response to the use of a lawful lockout during negotiations, employees could strike.

The question of how the implied contractual term of acting in good faith could be accommodated by the Act was first raised by the Court of Appeal in Telecom South Limited $v$ Post Office Union [1992] 1 ERNZ 711. In this case Cooke, P stated:

\begin{abstract}
there is an implied term in every employment contract that the employers will not, without reasonable and proper cause, conduct themselves in a manner calculated or likely to destroy or seriously damage the relationship of confidence and trust between the employer and employee $(711,715)$
\end{abstract}

The issue resurfaced in United Food \& Chemical Workers Union of NZv Talley [1993] 2 ERNZ 360 which involved a dispute over an employer's unilateral decision to terminate association with the employee's union. In this case, Hardie Boys J described the Act as," not anti-union but may fairly be described as union neutral" $(360,370)$. This position was further endorsed by the Court of Appeal in Eketone v Alliance Textiles (NZ) Ltd [1993] 2 ERNZ 786 where Cooke, P concurred that the Act is union neutral but went on to point out "there was no requirement for employers to be union neutral" $(786,787)$. This case was the long awaited appeal from Alliance Textiles which proved to be a major turning point in the development of bargaining case law.

It was not until two years after the Employment Court delivered the Alliance Textiles decision that the Court of Appeal finally addressed the questions of law on appeal. The appeal concluded that after such a delay no live issues remained to be resolved between the parties, the contract having expired and been replaced. The judgment however made important obiter comments, clarifying the fundamental rights and responsibilities of the employer and employee in the negotiation process. The Court of Appeal confirmed that under the Act, an 
employer was required to recognise the authority of the employees' bargaining representative but did not have to negotiate with them. The Court did, however, proffer a tentative opinion that if the employer wished to negotiate, bypassing an authorised representative or "to go behind the union's back does not seem consistent with recognising its authority" $(783,787)$

When dealing with the allegation of harsh and oppressive behaviour, the Court of Appeal could not avoid addressing the Act's failure to acknowledge the inherent imbalance of bargaining power -and the failure to make adequate statutory provisions to facilitate fair bargaining practices. Neither did the Act provide adequate protection against an abuse of bargaining power in extreme cases. In particular, those cases involving harsh and oppressive behaviour, where the requirements of s. 57 set a higher threshold than the common law relating to unfair or unconscionable contracts.

Significantly the Court of Appeal chose to draw on the New Zealand Bill of Rights Act 1990 and the International Covenant on Civil and Political Rights, which confirmed freedom of association as a fundamental right. The Court of Appeal concluded that it is appropriate to have regard to such international instruments when interpreting the scope of rights under the Act noting, "where it can be done (and the Bill of Rights Act requires it) the statute is to be given meaning consistent with freedom of association as internationally recognised" (786, 795). Notwithstanding these comments were obiter, they marked a significant shift in the legal institutions' interpretation of the Act from a narrow to a broad, holistic approach.

\section{A new era of holistic interpretation}

A new era of holistic interpretation was confirmed by the Employment Court's decision in NZ Medical Laboratory Workers. In this case an employer attempted to by-pass the authorised bargaining representative by circulating material about a new collective contracting policy directly to employees and by arranging meetings without first informing or inviting the union. The union sought a number of remedies including: declarations as to the legality of the employer's actions and a permanent injunction preventing interference with the union's bargaining authority. The employer argued that the freedom of expression granted by s.14 of the Bill of Rights Act 1990 allowed it to communicate directly with its employees. The union however maintained that any direct approach to employees who had authorised a bargaining representative was a direct contravention of s.12 of the Act.

From the outset the Employment Court made its intention clear that it would adopt the principles established in Eketone, stating:

that it did not agree that the observations in Eketone could be seen as obiter and therefore gratuitous. The views were expressed in an official judgment of the Court of Appeal with the concurrence of a full bench of five judges. The statements made indicate the likely line of policy to be adopted by the Court of Appeal in the future (123, 124-125).

In reaching its decision the Employment Court examined competing sections of the New Zealand Bill of Rights 1990 concluding that the freedom of expression afforded by s.14 of the Bill of Rights Act 1990 is qualified by s.5 which permits the law to place reasonable limits on freedom of expression such as those set out in s. 12 of the Employment Contracts 
Act 1991. The Court also identified Capital Coast Health's obligation to be a good employer under the Health and Disabilities Services Act 1993, s. 12 of the Fair Trading Act 1986, which prohibits misleading and deceptive conduct in relation to employment, and international instruments such as ILO Conventions 87 and 98 as relevant factors.

The Employment Court concluded that not all direct approaches to employees or attempts at persuasion breach s.12 unless the motive or intention was to undermine the authorised representative. In this particular case, the Employment Court found that a letter issuing conditional suspension notices in the context of a proposed strike was a conscious attempt to negotiate directly with employees and to interfere with intended strike action. This amounted to a breach of s.12(2) and the defendant's obligations of trust and confidence and its statutory good employer obligations. Accordingly the Employment Court issued a permanent injunction restraining the defendant from any conduct, including communications to its employees, that breached its duty to recognise the union's authority to represent its members.

Capital Coast Health appealed the Employment Court's finding in respect of four of the communications. Subsequently the Court of Appeal upheld the Employment Court's decision on all but one communication which was in the form of a warning letter setting out the financial consequences of strike action. Acknowledging the difficulty of drawing the dividing line between informing and warning (which is permissible) and threatening (which is not permissible), the Court concluded in this case that a communication setting out the legitimate steps an employer intends to take to minimise the cost of a strike, prior to strike action, was lawful.

Despite criticism during this case that such a broad approach increased the complexity of legal problems, leading to legal tests that unduly restricted the freedoms intended by the Act, the Court of Appeal remained committed to the approach established in Eketone stating:

The Act must be seen as essentially practical legislation designed to deal with everyday practical situations. It is not appropriate to subject it to esoteric analysis or draw fine distinctions in its application. It is a matter of striking a balance between the competing interests of the parties - those of the employee under s.14 of the Bill of Rights Act 1990 and those of the employee under s.12 of the Employment Contracts Act 1991. It is not a case of one prevailing over the other, but of both being given sensible and practical effect. (Capital Coast Health Ltd v NZ Med Lab Workers Union [1995] 2 ERNZ 320.)

Although this case failed to establish the dividing line on what constitutes behaviour that breaches s.12(2), by defining negotiation and answering the pivotal question as to whether the provision of information by the employer directly to employees is permissible, it confirmed the emergence of a broader interpretation of the Act.

\section{Communications with employees}

The issue of communications during negotiations resurfaced in the widely publicised case of Ivamy and Others $v$ New Zealand Fire Service [1995] 1 ERNZ 724. In this case, the employer, without any reference to the authorised bargaining representative, circulated a package of information to its employees containing information and conditions relating to the 
employees' future employment, including an inducement of $\$ 4,000$ for each employee who signed the contract before 31 March 1995. The packages were sent directly to officers incharge to distribute to firefighters. It was some hours before this information was passed on to union officials. In line with the approach taken in Southern Pacific Hotel Corp (NZ), Capital Coast Health and Eketone the Employment Court concluded that, "read as a whole Parliament intended the Act to create a climate under the broad umbrella of freedom of association with the overall aim of facilitating efficient and effective employment contract negotiations" $(724,766)$. The Employment Court confirmed that the direct approach by an employer to employees during negotiations was "objectionable" and the antithesis of play fair. It gave a clear directive that:

once negotiations for an employment contract had begun through an authorised employees' representative, no further communication on the subject of the negotiations should be addressed by the employer except for those required by the Act such as notices for lockouts or suspension of striking employees $(724,766)$.

The Employment Court further asserted that it must:

be taken to be a trespass on the employees' freedom of association for the employer, while negotiations are in progress, to seek to come between the employees and their representative by offering to employees arguments or inducements intended to have or having the effect of persuading the employees to act without waiting for advice from their representative or in disregard of that advice $(724,762)$.

The Employment Court justified its decision indicating that recent case law (Eketone and Capital Coast Health) meant the Court was less ready than before to support employers' perceived right to communicate directly with employees after a bargaining representative had been authorised. Furthermore, interpretation of employment disputes has extended to encompass the NZ Bill of Rights Act 1990 and the Privacy Act 1993. In particular the right to freedom of association established by s.17 of the NZ Bill of Rights Act 1990 has reinforced the freedom of employees to choose a bargaining representative. Similarly the Privacy Act 1993 makes the release of employee's personal information, such as remuneration rates, by the employer in media campaigns unlawful unless they first obtain the employee's consent.

This decision effectively imposed a blanket prohibition on communication regarding contract negotiation between an employer and its represented employees during contract negotiation. The decision sparked an outburst of criticism from employer groups who argued for their right to communicate directly with their employees. The judgment was seen as somewhat of a regression reminiscent of the uncompromising rigidities of the pre-Eketone era. Its impact was, however, short-lived. Within two months of the decision, Couling v Carter Holt Harvey Ltd [1995] 2 ERNZ 137 sought to restore a balanced and commonsense approach to bargaining.

The decision in Couling successfully lifted the blanket prohibition on communication during negotiations by distinguishing Ivamy on the facts before the Court. The case involved an action for a permanent injunction where an alleged breach of s. 12 occurred during collective contract negotiations. The mill management were instructed to relay the company's view of its position in the contract negotiations if asked. It transpired that several management staff 
did in fact communicate the company's position during conversations, some of which was in response to questions by employees while others were unsolicited.

The central issue for determination was whether the direct communications by management to employees constituted a refusal or failure by the company to recognise the authority of the union to represent the hourly paid employees during negotiations. During the judgment it was argued that such free and frank communications between management and employees were an established part of the workplace culture.

Noting that the Act does not define what constitutes a recognition of authority to represent under s.12(2), the Court adopted a broad interpretation relying on the Act's objective to promote an efficient labour market and the principles stated in Eketone and Capital Coast Health. It concluded that the decision of Ivamy did not extend the law in relation to s.12(2) of the Act. Colgan, J made it clear that a blanket prohibition on all direct communications between an employer and employees during contract negotiations would be unjust and impracticable. He concluded that "communications or information per se are not prohibited by statute" $(137,155)$. Only negotiations that have the intention or effect of undermining the representative's authority will constitute a breach of s.12(2).

The Employment Court accepted the defendant's submission that the intention of s.12(2) in the case of communications with represented employees during negotiations is to inhibit or prevent destructive, unfair or misleading communications. The Court, however, cautioned that each case would turn on its facts and concluded in this particular case that "the evidence does not satisfy me, on the balance of probabilities, that irrespective of motive there was an undermining or other failure or refusal to recognise the authority of the bargaining representatives" $(137,156)$.

This decision reflects a practical commonsense approach to negotiations where channels of communication can remain open without undue legal impediments.

The recent case of New Zealand Air Line Pilots' Association, Dallas Bean \& Ors v Airways Corporation of New Zealand unreported WEC 72/95 confirms the approach taken in Couling. This case involved a union application for a permanent injunction to restrain an employer against communicating with employees and third parties during contract negotiations. The Employment Court ordered permanent injunctions to stop the employer's communications where it could be established they were intended to undermine the authorised representative. The Chief Judge held that while an employer had the right to communicate with employees during contract negotiations it was not absolute. In this case several of the communications were found to be biased, slanted and not legitimate examples of the provision of factual information.

The approach taken in this case is consistent with that of the Court of Appeal in Capital Coast Health reaffirming the principle that each case must turn on its particular facts. During the decision the Chief Judge did however acknowledge the precarious legal position of the Employment Court concluding: 
I feel bound to say that the framers of the Employment Contracts Act 1991 could not have intended to leave so much room for judicial doubt and difference of opinion as has obviously been left by s.12 ... Perhaps Parliament will revisit the topic one day. I hope that day will come soon. It is asking too much to expect the courts to read the legislators' minds to the extent that has been necessary in these cases (WEC 72/95).

\section{The role of the specialist institutions}

There are several compelling reasons why a specialist jurisdiction should remain. An analysis of bargaining case law concludes that the much-vaunted era of "free bargaining" has led to workplace conflict which is costly and contrary to the Act's aims. Rather than playing the peripheral role envisaged by the Act, the new legal institutions have found themselves at the centre of bargaining conflict. Cognisant of their prescribed role under the Act, they were initially reluctant to intervene in the bargaining process. However, because the Act failed to provide the detailed provisions necessary to facilitate efficient bargaining, the legal institutions were left with little alternative but to intercede. Contrary to claims that the legal institutions have exhibited "extraordinary resistance" to the implementation of the Act, case law indicates they have applied themselves diligently to the difficult task of interpreting inconsistent, incomplete and philosophically flawed bargaining provisions in an effort to develop a workable bargaining structure. Far from sabotaging the Act, they have emerged as saviours of the bargaining system.

Neither does the case law support criticisms that the legal institutions have undermined the aims of Parliament by pursuing a minimalist approach and by implying terms not expressed in the Act. Such claims are reactionary and transparently self-serving. There is nothing unusual about court intervention in contractual arrangements to ensure a fair and just outcome. As Lord Denning noted, "a man's(sic) right to work is just as important to him, if not more important than his rights to property. Courts intervene every day to protect rights to property. They must intervene to protect the right to work" (Denning, 1979: 154).

Claims that the institutions resorted to "judicial mysticism" are likewise unfounded since there is nothing mysterious about the practice of implying terms in the absence of any express provisions. This is a logical and legitimate legal process, for as Cooke concluded, "The inevitable duty of the Courts is to make law" (Cooke, 1990: 4). Accordingly, in the absence of express statutory provisions, as is commonplace in the Act, the legal institutions had no option but to draw on past employment law precedents to resolve current legal problems. Where fundamental rights and freedoms are under threat, legal institutions have historically turned to a wider context of statutory and international law to develop new law. This is progressive, not regressive. The crux of these criticisms is not that specialist legal institutions have failed to operate in line with Parliament's intentions but rather, that their decisions did not accord with the economic agenda of their detractors.

Calls for the abolition of the specialist employment jurisdiction and a return to common law and commonsense also fail to recognise that the specialist institutions have, in practice, adopted a "commonsense approach" developed by the highest court in the land, the Court of Appeal. Establishing a general jurisdiction for employment law would not provide the 
outcomes sought by critics of specialist legal institutions. The common law of contract is dynamic and has long since progressed beyond classical principles of contract based on the shibboleths of freedom to contract and sanctity of contract. Modern courts of general jurisdiction no longer inflict legal rules that are out-moded and unjust. As Cooke observed "the sad fact is that the Courts evolved a law of contract which was so unjust in its workings that the legislature had to correct it on a major scale, giving back the Courts a control which they should never have abandoned by self-imposed doctrine" (Cooke, 1990: 2).

While the Act created "new" legal institutions, their role remains fundamentally unchanged. Progressively they have come full circle, reaffirming the conclusion reached by Pember Reeves over a century earlier, that judicial intervention is necessary to "fairly hold the scales between employer and employed" (Deeks, 1982: 24). The specialist legal institutions have, contrary to the claims of their critics, succeeded to the extent that they have maintained a dynamic equilibrium where the scales of dissatisfaction are fairly evenly balanced. Unlike their predecessors, however, who had a statutory mandate to intervene, they continue to labour in "less than a fully certain and stable legal situation" (Goddard CJ, WEC 72/95). Reworking bargaining provisions is long overdue.

\section{References}

Boxall, P. (ed.) (1995), The Challenge of Human Resource Management, Auckland, Longman Paul.

Cooke, Rt Hon Sir Robin (1990), Dynamics of the Common Law. Paper presented at the 9th Commonwealth Law Conference.

Department of Labour (1995), Contract: The Report on Current Industrial Relations in New Zealand, 15.

Department of Labour (1996), Contract: The Report on Current Industrial Relations in New Zealand, 16.

Deeks, J., Roth, H., Farmer, J. and Scott, G. (1982), Industrial Relations In New Zealand, Auckland, Longman Paul.

Denning, Lord (1979), The Discipline of Law, London, Butterworths.

Grills, W. (1994), The Impact of the Employment Contracts Act on Labour Law: Implications for Unions, New Zealand Journal of Industrial Relations, 19(1): 85-101.

Harbridge, R. (ed.), (1993), Employment Contracts: New Zealand Experiences, Wellington, Victoria University Press.

Harbridge, R. and Honeybone, A. (1995), Trade Unions under the Employment Contracts Act: Will slimming be fatal? In Boxall, P. (ed.). The Challenge of Human Resource Management, Auckland, Longman Paul. 
Industrial Relations Centre (1995), Victoria University, Wellington. Anmual Review for 1994. In The Independent, 14 July, 35.

Keily, P. and Caisley, A. (1993), The legal status of bargaining under the Employment Contracts Act 1991: a review of recent cases. In Harbridge, R. (ed.). Employment Contracts: New Zealand Experiences, Wellington, Victoria University Press.

Howard, C. (1995); Interpretation of the Employment Contracts Act 1991, Wellington, New Zealand Business Roundtable and New Zealand Employers' Federation.

National Party (1991), Manifesto.

\section{Cases}

Adams v Alliance Textiles (NZ) Limited [1992] 1 ERNZ 982.

Armstrong v Attorney-General [1995] 1 ERNZ 43.

Billing v Wellington City Council unreported WEC 33/95.

Buchanan v Rodney District Council [1992] 2 ERNZ 578.

Butters v Forestry Corporation of New Zealand Limited unreported AET 880/92.

Capital Coast Health v NZ Med Lab Workers Union [1995] 2 ERNZ 320.

Couling v Carter Holt Harvey Ltd [1995] 2 ERNZ 137.

Eketone v Alliance Textiles (NZ) Ltd [1993] 2 ERNZ 783.

Foodstuffs (Auckland) Ltd v National Distribution Union Inc. 2 NZLR [1995] 284.

Grut v Downer Mining [1992] 1 ERNZ 982.

Hawtin v Skellerup Industrial Ltd [1992] 2 ERNZ 500.

New Zealand Air Line Pilots' Association, Dallas Bean \& Ors v Airways Corporation of New Zealand unreported WEC 72/95.

New Zealand Nurses v Argyle Hospital Ltd [1992] 2 ERNZ 314.

New Zealand Baking Trades Etc Union (Inc.) v Foodtown Supermarkets Limited [1992] 3 ERNZ 305.

NZ Dairy Workers Union Inc. v Hautapu Whey Transport Ltd [1992] 2 ERNZ 568. 
NZ Engineering Union Inc and Ors v Shell Todd [1994] 2 ERNZ 546.

NZ Medical Laboratory Workers Union v Capital Coast Health Ltd [1994] 2 ERNZ 123.

New Zealand Professional Firefighters Union v The New Zealand Fire Service Commission [1995] 1 ERNZ 320.

Service Workers Union of Aotearoa Inc. v Southern Pacific Hotel Corp [1993] 2 ERNZ 513

Shannon v Pacer Kerridge Cinemas Limited [1992] 3 ERNZ 742.

Sidebotham and Powell v Capital Coast Health Ltd [1994] 2 ERNZ 431.

Skellerup Industries Ltd v NZ Rubber Workers Union [1992] 1 ERNZ 477.

Telecom South Limited v Post Office Union [1992] 1 ERNZ 711.

United Food and Chemical Workers Union v Talley [1993] 2 ERNZ 360. 